\title{
Borges and the Politics of Language in the 1920s
}

\author{
Christopher D. Warnes Pacheco ${ }^{1}$
}

In "El idioma infinito," one of Jorge Luis Borges's many essays regarding language in the $1920 \mathrm{~s}$, the author calls for a "politics of language" intended for the Spanish of the River Plate. Forming part of the Argentine literary avant-garde, he is keenly interested in the development of language and, more importantly, who is to maintain it. Are the literati to allow a natural development of language and produce texts and analyses that mirror its transformation, or are they to intervene and prescribe how a language ought to be used? By studying Borges's positions on spelling and vocabulary, the present analysis notes that his "politics of language" in the 1920s promotes a descriptive and natural development of Spanish, more akin to the laissez-faire approach adopted by intellectuals of English than the Spanish of the regulatory Real Academia Española. [Article copies available for a fee from The Transformative Studies Institute. E-mail address: journal@transformativestudies.org Website: http://www.transformativestudies.org (C2020 by The Transformative Studies Institute. All rights reserved.]

KEYWORDS: Borges, Language, Spelling, Vocabulary, Real Academia Española, 1920s.

There is no doubt that one of Jorge Luis Borges's primary interests throughout his career is language. This is especially true when considering his first decade as a poet and essayist in the Buenos Aires of the 1920s. During this period, a group of Argentine writers, including Borges, Ricardo Güiraldes and Eduardo González Lanuza, rebel against traditional academic institutions and become captivated by the "spirit of "the new" - a movement Beatriz Sarlo labels "avant-garde criollismo" (Sarlo 131). In addition, decades of mass immigration to Buenos Aires

1 Christopher D. Warnes Pacheco is currently a Ph.D. student in the Hispanic Languages and Literature Department at the University of Pittsburgh. His main areas of study include Jorge Luis Borges, $20^{\text {th }}$ century Latin American fiction and applying digital methods to the humanities. Address correspondence to: Christopher Warnes; e-mail: cdw27@pitt.edu. 